\title{
Deparliamentarization in Turkey: A Major Decline in the Scrutiny Function
}

\author{
Türkiye'de Parlamentonun Güç Yitirmesi: Denetim İşlevinde Büyük \\ Gerileme
}

\author{
Mehmet KABASAKAL
}

\begin{abstract}
In parliamentary democracies, governments are formed through parliamentary elections, and both the cabinet and budget must receive the confidence of the legislature. The "golden age", when parliaments make laws without any pressure from the executives and have strong control over cabinets, ended by $20^{\text {th }}$ century. For the last few decades, however, legislative studies have been pointing to a shift in the balance of power from the legislative to the executive branch in many countries. The declining power of parliaments is explained by many factors. Scholars who studied "declining parliaments" generally agree on the commonly accepted contributing factors for deparliamentarization. These factors are "constitutional arrangements, increasing global regulations, the complexity of issues and technicalfocus in policy making, disciplinary party structures, the lack of intra-party democracy, the domination of parties by their leaders, and electoral systems." Although a trend of deparliamentarization has been noted, mainly in parliamentary democracies, the decline of parliaments has not been as glaring and forbidding everywhere. Thus, the variation, especially among similar democratic systems, calls for a closer analysis of country cases. This study examines Turkey, and discusses the changes regarding the power balance between the executive and legislative branches of government by identifying the pattern of changes in constitutions and country's electoral system, and party structures which tend to stress party discipline and maintain leaders' control. The paper analyzes the politics of Turkey between 1946 and 2014 especially by focusing on the AKP rule after 2002. The power shift in Turkey has been from parliamentary supremacy to a very strong executive, and deparliamentarization has been particularly rapid and profound since the 1980s,. In 2017, a change in the constitution allowed a transition to a presidential system and the new system is legalized by the constitutional amendments. The paper concludes with the analysis that there is a significant decline in the power of the parliament in Turkey, after 1980s, mainly in its scrutiny function. The longitudinal study of changes shows that deparliamentarization, or the increase in the power of the executive, was caused by multiple domestic and international factors that occurred simultaneously and reinforced each other's impact. The significant difference of Turkey from the other world cases are rapid constitutional changes, increasing leader authority within the parties, and existence of dominant party system in Turkey since 15 years.
\end{abstract}

* Dr., Istanbul Okan University, Faculty of Business and Administrative Sciences, International Relations Department, Mehmet.kabasakal@okan.edu.tr, Orcid: 0000-0002-1097-6467 
Keywords: Functions of parliament, declining parliaments, separation of powers, check and balance, powerful executive, leader dominance, parliamentary scrutiny

Öz

Parlamenter demokrasilerde hükümetler genel seçimlerle oluşan meclislerde şekillenir. Kabinenin kurulup icraata başlayabilmesi için daha başlangıçta meclisten güvenoyu alması gerekir, ayrıca, her yıl ulusal bütçesini meclise sunarak onaylatmak zorundadır. Parlamentoların yürütmenin herhangi bir baskısı olmadan yasa yaptıkları ve hükümetler üzerinde güçlü denetim kurdukları altın çağ” 20. yüzyılda sona ermiştir. Son 30-40 yılda parlamentolar üzerine yapılan çalışmalar, birçok ülkede güçler arasındaki dengenin bozulduğuna ve yasamadan yürütmeye güç kayması olduğuna işaret etmektedir. Parlamentoların güç yitirmesi birçok nedenle açıklanmaktadır. Yasama organlarının güç kaybının nedenleri üzerinde çalışan akademisyenler, yaygın kabul gören bazı etkenler konusunda görüş birliği içindedirler. Bu etkenler, kısaca anayasa değişiklikleri, küresel düzenlemeler, yasama gündemindeki konuların giderek karmaşıklaşması ve politika oluşturmanın gittikçe daha teknik bir hal alması, parti disiplini, parti içi demokrasinin yokluğu ve lider hegemonyası ile seçim sistemi olarak ifade edilmektedir. Yasamanın güç kaybı, esas olarak parlamenter demokrasilerde görülmektedir, ancak bu güç azalması her ülkede aynı oranda ve biçimde değildir. Benzer demokratik sistemlerde bile görülen farklılıklar, ülke bazında ayrıntılı incelemeleri zorunlu kılmaktadır. Bu çalışma Türkiye örneğinde yasama ve yürütme arasındaki güç dengesini, anayasal değişiklikler, ülkenin seçim sistemi, parti disiplinini etkileyen ve liderin denetimini pekiştiren parti yapıları açısından incelemektedir. Çalışma, 1946 ile 2014 arasındaki dönemi ele almakla birlikte özellikle 2002 sonrası AKP iktidarı dönemine yoğunlaşmaktadır. Türkiye’de meclis üstünlügünden güçlü yürütmeye geçiş 1980 sonrasında daha hızlı ve yoğun olmuştur. 2017'deki referandumla yapılan anayasa değişiklikleri ile de Türkiye'ye özgü başkanlık sistemi yasallık kazanmıștır. Bu yazı sonuç olarak, Türkiye’de parlamentonun önemli ölçüde güç yitirdiğini, bu kaybın da özellikle 1980 sonrasında gerçekleștiğini ortaya koyan betimleyicitanımlayıcı bir çalışmadır. Parlamentoların güç kaybına veya yürütmenin gücünü artırmasına neden olan değişikliklerin ayrıntılı incelenmesi, bu süreçte birçok yerel ve uluslararası etkenin aynı zamanda birbiriyle etkileşim içinde rol oynadığını göstermiştir. TBMM de dünyada birçok parlamentoda gözlenen güç kaybını özellikle denetleme işleviyle ilgili olarak yaşamıştır. Türkiye’de güç kaybına neden olan etkenler, bu ülkelerden bazı niceliksel farklılıklar göstermektedir. Türkiye’de öne çıkan etkenler, sık sık anayasa değişiklikleri yapılması, partilerde lider otoritesinin son yıllarda giderek artması ve 15 yıldır Türk siyasal yaşamında pekişmeye başlayan "hakim parti" sistemidir.

Anahtar sözcükler: Parlamentonun işlevi, parlamentonun güç yitirmesi, güçler ayrımı, denetim ve denge sistemi, güçlü yürütme, lider hegemonyası, meclis denetimi

\section{Introduction}

In parliamentary democracies, governments are formed through parliamentary elections, and both the cabinet and budget must receive the confidence of the legislature. Representing the popular will, elected legislatures are the main and indispensable institutions of democratic systems (Dahl, 1971, p. 3-20; Diamond, Linz, and Lipset, 1995, p. 6-7; Schmitter and Karl, 1991, p. 75-88; Uluşahin, 2016, p. 39-66). The "golden age" when parliaments made laws without any pressure from the executives and had strong control over cabinets, ended by the 20th century. Recently, their representation functions were questioned by the scholars who focus on the civic society and participative democracy (Adams, 1970; Beetham and Boyle, 2005; Diamond, 1999, p.1-18; Gallagher, 2014, p.11-27; Hirst, 1990, p. 22-37; Hooghe; 2014, p.58-74; LeDuc, Niemi and Norris, 2014, p.1-10; Offe, 1996, p.94; Schmitt, 1988 and 2006; Sunar, 2010, p.16-19). Offe (1996, 
p. 94) also pointed out that "In the long history of incisive literature on the subject, numerous flattering assumptions have been made about the qualities of legislative representative bodies, specifically with regard to their rationality, reasonableness, maturity, knowledge of the material, impartiality, collective intelligence, and capacity for judgement." Although Offe suggests that there is no alternative to liberal democracy, "the will of the people" exhibits some problematic features: it is fictitious, fallible, and seducible (p.90-91). The procedures that are used to arrive at the will of the people become "the will of those in political office".

In addition to the problem of representation, for the last few decades, students of democracy and legislative studies have been pointing to a shift in the balance of power from the legislative to the executive branch in many countries, including the United Kingdom, France, Spain, Italy, Greece, Australia and Canada (Crimmins and Nesbitt-Larking, 1996; Haynes, 2005; Liebert and Cotta, 1990, p. 8-13). Referred to as "declining parliaments" or "deparliamentarization," this trend is noted to be most profound in parliamentary democracies (Baldwin, 2004 and 2006; Blondel, 1973; Bryce, 1921; Elgie and Stapleton, 2006; Loewenberg, 1971; Olson and Norton, 1996; Norton, 1998; Raunio and Wiberg, 2008).

There were not any previous studies about "declining parliaments" or "deparliamentarization," in Turkey. The only study that examined the trend of deparliamentarization in Turkey mainly focused on the indicators of deparliamentarization in Turkey for the 1946-2014 period (Kabasakal, 2018). In this paper I examine the factors that caused or facilitated that trend, by analyzing their effect on different functions of the parliament. I show that the power of the parliament has been declining gradually, though not always in a smooth linear pattern. The decline has been more profound since 1980 and gaining momentum during the last decade. More recent studies about the existence of dominant party system (Ayan-Musil, 2014; Canan Aslan-Akman, 2012; Çarkoğlu, 2011; Gumuscu, 2012) also emphasized the decline of parliaments in Turkey.

Turkey has failed to establish a stable democratic regime, but since the establishment of the Republic in 1923, it maintained an elected parliament. After the transition to multi-party electoral system in 1946, the country aspired to be a parliamentary democracy, and the politics of Turkey between 1946 and 2014 have been typically studied in the paper.

During the last decades, Turkish politics have been subject to some sudden and unexpected changes. The power of the executive increased either by the constitutional changes or de facto applications of prime ministers, and the Turkish Grand National Assembly (TGNA) started to lose its control over the parliament. According to Haynes, during the last decade "the AKP, under Prime Minister Erdoğan, controlled parliament single-handedly” (2010, p. 323). In 2007, a change in the constitution allowed for the popular election of the president of the Republic, and the election of the ruling party's leader to the position in 2014 resulted in a de facto presidential system, operating outside of the constitutional framework (Uluşahin, 2016, p. 53-57). This shift was legalized through a constitutional amendment adopted in a referendum held on April 16, 2017. The change in the constitution engendered a "Turkish-style" presidential system that 
eliminates the mechanisms of overview by the parliament and judiciary, thus effectively ends the checks and balances maintained in presidential democracies, and equips the office of the president with extraordinary powers that are common in authoritarian systems of one-person rule. According to the new constitutional amendments, even the members of the TGNA are not able to ask verbal questions to the cabinet members. The president will have authority to prepare national budget - which is considered one of the premier functions of the parliaments. This shift makes the study of factors that had led to the decline of the parliament in Turkey in the preceding years even more important.

Table I. An Overview of Government Systems in Turkey, 1920-20I8

\begin{tabular}{|c|c|}
\hline Years & Type of Government Systems \\
\hline $1920-1923$ & $\begin{array}{l}\text { Parliamentary Government (no formal party system) } \\
\text { Assembly could appoint, instruct and change each minister at will. }\end{array}$ \\
\hline $1923-1945$ & $\begin{array}{l}\text { Parliamentary Government, One-Party Rule } \\
\text { Both legislative and executive powers were concentrated in the } \\
\text { Assembly, which could at any time dismiss the Council of Ministers, while the Council had no } \\
\text { power to dissolve the Assembly to hold new elections. But the party leader controlled both the } \\
\text { legislative and executive. }\end{array}$ \\
\hline $1946-1960$ & $\begin{array}{l}\text { Multi-party Regime, without checks and balances } \\
\text { Both legislative and executive powers were concentrated in the Assembly, which could at any time } \\
\text { dismiss the Council of Ministers, while the Council had no power to dissolve the Assembly to hold } \\
\text { new elections. }\end{array}$ \\
\hline 1960-1961 & Military Government \\
\hline 1961-1980 & $\begin{array}{l}\text { Multi-party Regime, with separation of powers } \\
\text { Westminster rules of checks and balances between the executive and legislative were established } \\
\text { and judicial review was introduced. } \\
\text { Election system changed as PR. Coalition governments appeared. } \\
\text { After } 1971 \text { power of executive started to increase with the } \\
\text { Amendments of 1961Constitution. }\end{array}$ \\
\hline 1980-1983 & Military Government \\
\hline 1983-2014 & $\begin{array}{l}\text { Parliamentary system, with separation of powers } \\
\text { Though, the President, with some appointment and veto powers. enjoyed more than symbolic } \\
\text { power, } \\
\text { After 2011, hegemonic party rule and very strong executive. }\end{array}$ \\
\hline 2014-2016 & $\begin{array}{l}\text { De facto Presidential system, weak checks and balances } \\
\text { Partisan president exercising the authority of the prime minister. }\end{array}$ \\
\hline 2016 - present & $\begin{array}{l}\text { De facto Presidential system, with no checks and balances } \\
\text { Partisan president exercising the authority of the prime minister and ruling by decree in a } \\
\text { continuous state of emergency. }\end{array}$ \\
\hline
\end{tabular}

Thus, this study intends to contribute to the literature that examines causes of deparliamentarization in Turkey during the parliamentary system between 1946 and 2014, especially focusing on the AKP rule. I start with a review of the commonly accepted contributing factors, which include: constitutional arrangements, increasing global regulations, the complexity of issues and technicalfocus in policy making, the role of media, emergence of new organizations, disciplinary party 
structures, the lack of intra-party democracy, the domination of parties by their leaders, and electoral systems. After the review of the prevailing arguments on the global trend of expanding executive power and declining parliaments, I shift my attention to Turkey and examine the process of deparliamentarization and the contributing factors over the years.

\section{The Thesis of Declining Parliaments}

Functions of the legislative and executive branches and their power over each other are not new topics of interest for those who have been studying liberal democracies. Based on their comparative study of four political systems existing in 17 countries located in six geographic regions (North America, South America, West Europe, Asia, Africa and Middle East), Gerhard Loewenberg and Samuel C. Patterson point to the intertwined functions of the branches:

A neat separation between legislatures making laws and executive carrying them out does not exist in any of the political system we have examined. Such separation probably does not exist anywhere, simply because policy making cannot be neatly separated into lawmaking and law implementing. As a result, legislatures and executives are separate institutions sharing policy making in different proportions in different countries (1988, p. 277).

The Decline of Legislatures, was first mentioned by Lord Bryce in 1921; he discussed the problem of reduced "prestige and authority of legislative bodies" as a trend displayed by the major democratic regimes at the time (Bryce, 1990, p. 47-56). Jean Blondel described the pattern as follows: “....in the postwar years, legislatures of Western European states often seemed to become increasingly streamlined and increasingly confined to obeying the fiats of strong executives backed by a disciplined party." Blondel reached a bold conclusion: "Legislatures are rarely 'strong.' Even in 'liberal democracies' many complain about their impotence, their decline, their ineffectiveness and if they are strong, they are often blamed for their inconsistency, their squabbles, and thus the same ineffectiveness" (1973, p. 3-6). Similarly, Loewenberg found the role of most parliaments in the process of policy-making rather limited (1971).

Although the executive power has been expanding in all systems, observers also note that the decline of parliaments has been most common in Westminster-style systems (Crimmins and Nesbitt-Larking, 1996; Dunleavy, Jones, and O'Leary, 1990; Liebert and Cotta, 1990; Raunio and Wiberg, 2008; Thomas, 2004). Thus, factors that cause or facilitate this trend emerged as an area of interest for scholars working on legislatures, separation of power, and democracy.

In contemporary democracies parliaments carry out different functions, such as representation of people, enacting laws, levies taxes, scrutiny and control of executive affairs. Legislature is elected by and representative of the people (Beer, 1973, p. 206-218; Loewenberg and Patterson, 1988; p.43-67; Pennock and Smith, 1964, p. 380-389). Law-making by discussion and debates 
is considered as the main function of the parliaments (Martin, 2004, p.445). Parliaments also contribute to the formation of the cabinets by giving "vote of confidence." Legislatures may accept or reject the country's national budget. Approval of international agreements is known as one of the ordinary function of the parliaments. Criticism and control of the executive are realized by the parliaments on behalf of the electorates (Auel, 2007, 494-497). This paper also analyzes which of these functions of the parliament are declining in Turkey.

\section{Factors that lead to the decline of the parliament}

Focusing on the relative policy impact of the legislative and executive branches, Philip Norton and David M. Olson offer two explanations that would draw attention to a range of variables (Norton and Olson 1996; Norton 1998). The first one contends that "the capacity of legislatures to affect public policy is determined by variables largely beyond their control." In other words, the decline of legislature's power is determined by the external environment. The second argument holds that "variables specific, or internal, to the legislature can determine its ranking, and that its capacity to influence policy outcomes is greatest when it is highly institutionalized" (Norton 1998, p. 2-5, and p. 195-196). Institutionalization, of course, also has various features. Thus, studies on the declining power of parliaments point to a range of explanatory factors (Pridham, 1990, p. 225-248; Olson and Norton, 1996, p. 6).

In this section, I briefly discuss these inter-related external and internal factors that are mentioned or stressed in the literature. They include: expansion of global governance and its demand of technical expertise; legislature's increasing reliance on committees; strong party discipline; electoral laws; constitutions.

Regarding external factors, some highlight the impact of globalization. With the expansion of global governance and proliferation of global intergovernmental organizations (Auel, 2007, p.497500 and 503-504), they note, the policy-making processes have become even more complex and technical. Parliaments supposed to make laws while executive carries them out, but it is difficult to sustain this distinction in practice. Because of the technical complexity of the issues and limited members and staff who were expert on those issues, parliaments may be forced to carry out the process, and delegate a great deal of authority to the executive branch by the constitution (Epstein and O'halloran, 1999, p. 18-29). On the other hand, parliaments increasingly rely on specialized committees to expedite bills, and most of the legislatures today have specialized committees that correspond to the major functions of the government. The increased specialization and technicalfocus in policy-making, as well as regulations by intergovernmental organizations, help augment the executive power (Olson and Norton, 1996, p. 11; Turan, 2000), and decrease the power of the parliament related with the law-making function.

The composition of the membership of committees is another independent variable. Members may be chosen because of their knowledge of the sector covered by the committee. Also, they may be chosen because of their seniority in the party parliamentary group. Moreover, since the 
committee membership is determined by the party composition of parliaments (Shaw, 1990, p. 241), committee chairs are typically held by the dominant party. As the dominant party is likely to form the government, the system allows the executive to control or influence the activities of committees. This may cause the decline of law-making power of the parliament.

A powerful executive consists of members who are subject to the discipline of well-organized political parties. Thus, although the legislature as a whole cannot tell the executive what to do, the caucuses of those parties who are in government can effectively impose policy upon "their" ministers (Laver and Shepsle, 1994, p. 7). It is also noted that strong party discipline, as most common in the Westminster model, allows the party leader to control the party's representatives in the parliament. This enhances the power of the executive, who is typically the leader of the governing party.

Party leaders, in return, "would like nothing better than a majority in the legislature made up of like-minded individuals willing to vote early and often in accord with the leader's suggestions" (Bowler, Farrell and Katz, 1999, p. 9; Özbudun, 1970, p. 305). Therefore, increasing authority of party leadership and strong party discipline should be included among the factors that facilitate the decline of parliaments (Puhle, 2002). Jean Blondel and Maurizio Cotta, by examining 11 countries during the 1980s and early 1990s, accepted the importance of the influence of parties on governments, especially in European political systems (1996). Noting that the party that has the majority in the parliament also forms the government, it is argued that in parliamentary systems the legislative and executive powers are fused and it is not possible for the legislature to check and balance the executive power.

Electoral laws are principal instrument for trying to shape the contours of the party system. There is no perfect way to reconcile or maximize both efficiency and representativeness (Diamond, Linz, and Lipset, 1995, p. 36-37). According to David Farrell, "all electoral systems distort the election result, with some parties benefiting more than others. The best a proportional electoral system can hope to achieve is to minimize the degree of distortion." (1997, p. 7) The electoral systems, which convert ballots into seats, of course, also play a role in determining the level of fragmentation within the parliament and the type of government (Lijphart, 1999). The partylist proportional representation systems are likely to be associated with the central allocation of nominations. By contrast, district-based electoral systems tend to be associated with more localized control over nominations. Then, whether the process of candidate nomination is controlled locally or nationally should have a clear impact upon where the legislative members direct their loyalty (Laver and Shepsle, 1999, p. 7-8). Therefore, both the party discipline and electoral laws may affect the power of the parliaments, especially their representation and control functions.

Formally, in almost every parliamentary democracy, the parliaments are sovereign. Their legislations are constrained only to be consistent with the constitution as interpreted by the highest court of the country (Laver and Shepsle, 1994, p. 293). Constitutions stipulate the relationship 
between the different parts of the political system both horizontally and vertically. They describe, explicitly or implicitly, the relative power of each branch and the procedures through which they may control each other (Norton, 1998, p. 6; Crick, 1990). Constitutional changes, not common in established democracies but frequent in new and fragile democracies, are considered among the factors that explain the declining power of parliaments, and affect all functions of the legislatures.

\section{Factors that Lead to the Decline of the Parliament in Turkey}

The Republic of Turkey started as a parliamentary government that allowed the parliament, the Grand National Assembly (GNA), to appoint, instruct and change each cabinet member at will. It was also dominated by a single party and functioned as a one-party rule for over two decades. After the transition to multiparty system in 1946, the political system of the country was transformed into a parliamentary democracy. Although it failed to fulfill the democratic aspirations of the public and became subject to several military interventions, the system maintained the institutional characteristics of a parliamentary democracy until 2014. Parties competed to gain the control of the parliament, and the largest party in the parliament formed the government and sought the parliaments' vote of confidence. The chief executive, the Prime Minister, came out of the parliament and headed a government responsible to the parliament. The power of the President of the Republic remained largely symbolic. As the head of the state, the President was expected to be above party politics and filled through a near consensus of the members of the parliament (MPs).

However, even when it displayed main elements of a parliamentary system between 1946 and 2014, Turkey experienced a variety of government systems, as summarized in Table 1. Documenting and explaining power shifts in favor of the executive in Turkey would allow us to understand not only how the pattern of declining parliament ultimately resulted in a regime change but also test the relevance of explanatory factors employed in other country studies.

As indicated above, Philip Norton insists that the explanations for any case of declining parliaments need to address numerous features of both external and internal environments in which the legislature functions (1998). While his reference to external and internal applies to the boundaries of the legislative branch, I apply them to the country and examine the issue of declining parliament for the case of Turkey by considering the domestic and global factors, which interact and influence each other.

\section{A. Domestic Factors}

Among the domestic factors that affect the relative power of the parliament, we can include the constitutions of the country, electoral system, political party structure, and the role of the media and other organizations. 


\section{The Constitutional Framework}

The constitution of a country regulates the relations among the executive, legislature, and judiciary branches; determines the rules of political life, and draws the boundaries of the executive power (Powell, 1982). Therefore the relative powers of the legislature, executive and judiciary branches are mainly defined in the constitutions.

The first constitution of Turkey was issued in 1921. Since then, the republic has had three more constitutions, issued in 1924, 1961 and 1982, and the latter two have been subject to numerous and often substantial amendments. First Grand National Assembly (GNA) was fully assumed both the legislature and executive power, and exercised judiciary power to some extent (Soysal, 1979). The GNA claimed to be the only legitimate representative of the nation, and there was no organized political party in it. When the Assembly issued a constitution in 1921, it provided the GNA with more power than any other state agency. Members of the Council of Ministers (the cabinet) were elected directly by the GNA, and each minister was directly and individually responsible to the Assembly. Moreover, the Chair of the GNA also served as the Chair of the Council of Ministers.

After the declaration of Republic in October 29, 1923, the national Assembly adopted a new constitution in 1924. "Theoretically, both legislative and executive powers were concentrated in the Assembly." (Özbudun and Gençkaya, 2009, p. 11) According to Karpat, "The fundamental principle behind it was the concentration of all three government powers in the one-house National Assembly." (1959, p. 45) Karpat also noted that the GNA had "absolute supremacy over the Executive and Judiciary" (1959, p. 459). The Constitution of 1924 authorized the GNA, the President, and the Council of Ministers to exercise both the legislature and the executive power jointly and assigned the judicial power to independent courts. During the Assembly debates on the Constitution "most deputies were intent on jealously preserving the dominant position of the Assembly" (Kili, 1971, p. 30-63). Therefore, theoretically there was an imbalance of power in favor of the parliament. For example, "The Assembly could at any time supervise and dismiss the Council of Ministers, while the Council had no power to dissolve the assembly to hold new elections" (Özbudun and Gençkaya, 2009, p. 11). The President was elected by the Assembly but he could not dissolve it. On the other hand, the PM could control the party and, by default, the Assembly, especially if he was also the party chair (Karpat, 1959, p. 459).

As the democratic rule was interrupted by a military coup in May 1960, in transition to the civilian rule, a new constitution was devised and adopted through a referendum in 1961. The new constitution emphasized the separation of powers; brought the horizontal accountability; ${ }^{1}$

1 Horizontal accountability indicates an important distinction from traditional forms of accountability, where subordinate usually reports to a superior (hence these can be called vertical forms of accountability). Horizontal accountability addresses the relationship between the equals, or the different constitutional powers of the state. For more information about horizontal and vertical accountability, see Thomas Schillemans, (2008), "Accountability in the shadow of hierarchy: The horizontal accountability of agencies, Public Organization Review, June 2008, (8):175194; Yannis Papadopulos, (2003), "Cooperative forms of governance: Problems of democratic accountability in complex," European Journal of Political Research, 42: 473-501; Tom Christensen and Per Laegreid, “The whole of 
it aimed at balancing the power of executive and legislative branches and increased the judiciary control over them (Özbudun and Gençkaya, 2009). It attempted to introduce checks and balances by creating some new agencies such as the Senate (the upper house), the Constitutional Court, the Supreme Council of Judges, and the National Security Council. These changes in the new Constitution aimed at limiting the power of the executive. The creation of a bicameral parliament split the legislative power and intended to prevent hasty legislation by the lower chamber, since the bills and proposals were to be debated first by the National Assembly, the lower chamber, and then by the Senate of the Republic of Turkey.

Nevertheless, the checks and balances introduced by the new Constitution, along with the expanded freedoms and fundamental rights, made the constitution a target of frequent criticisms by powerful right-wing political party leaders, media and intellectuals. They argued that the executive was not able to perform its tasks effectively due to the monitoring by the high courts (e.g., Danıştay), the slow legislation process that now involved debates in two chambers, and the reviews by the Constitutional Court (Gözübüyük, 1997, p. 129-130). These complaints, eventually served as justifications for the constitutional amendments that were carried out after a military intervention that took place in 1971. These amendments not only limited the fundamental rights significantly, reduced the judiciary oversight of the executive and legislature branches, but they also increased the power of the executive by authorizing the cabinet to issue decrees that could be enforced as laws, and limited the MPs' ability to question the PM and other cabinet members in the parliament.

Another military coup, which took place in September 1980, dissolved the parliament, and established a consultative assembly to devise new constitution. Following a public referendum, the constitution was adopted in 1982. Attempting to create a powerful executive at the expense of the legislative and judicial branches (Kalaycıoğlu, 1988, p. 61), the 1982 Constitution abolished the Senate and expanded the executive power. It also enhanced the power of the President, by granting the office the right to choose and appoint judges of the high courts, in addition to giving it veto power over the legislative branch. Moreover, it replaced the former "The Supreme Council of Judges" with "The Supreme Council of Judges and Prosecutors" (Hakimler ve Savcilar Yüksek Kurulu, HSYK), the membership which was expanded to include the Minister of Justice and the Undersecretary of the Minister of Justice. A new law, proposed by the governing party and enacted in early 2014, included certain provision that further enhances the influence of the Minister of Justice over the judiciary. The constitutional amendments adopted in a referendum held on April 16, 2017, gave new massive powers to President who would maintain the party leadership and continue to select her/his party candidates for TGNA, to select the members of the Constitutional Court and those of the HSK. ${ }^{2}$

government approach to public sector reform," Public Administration Review, 67, (6): p.1059-1066; and Katrin Auel, (2007), "Democratic accountability and national parliaments: Redefining the impact of parliamentary scrutiny in EU Affairs, European Law Journal, 13, (4): p. 487-504.

2 Name of "The Supreme Council of Judges and Prosecutors" (Hakimler ve Savcllar Yüksek Kurulu, HSYK) was also changed by the 2017 Amendments as "The Council of Judges and Prosecutors" (Hakimler ve Savcilar Kurulu, HSK). 
Both the 1961 and 1982 Constitutions define the duties and powers of the TGNA as, to enact, amend and repeal laws, to debate and adapt the bill on the state budget and final accounts, supervision and scrutiny (questions, general debates, parliamentary investigations and parliamentary inquiries, interpellations) and ratification of international treaties.

The 1982 Constitution also reduced the power of the legislature by limiting the MPs' ability to act individually. It limited the right to appeal to the Constitutional Court only to the President of the Republic and at least 20 per cent of (more than 40) the MPs. It further restricted the parliamentarians' ability to apply to the Constitutional Court by reducing the application time for the review from 90 days to 10 days.

Similar to the 1971 amendment to the 1961 Constitution, the 1982 Constitution authorized the government to issue decrees having force of law (Article 91), ${ }^{3}$ although Article 7 of 1982 Constitution declares that "Legislative power is vested in the Grand National Assembly of Turkey on behalf of the Turkish Nation. This power cannot be delegated." Over the years, governments operating under the 1982 Constitution exercised the authority to issue such decrees at an increasing rate (Kalaycioğlu, 1990, p. 204). Until the last decade, Özal governments ranked at the top of the list of executives that took advantage of this provision that passed over the parliament. Then, Erdoğan governments started to make a habit of governing by decrees, ${ }^{4}$ leading news reporters to point out that "Although the parliament is in session, the government is ignoring the Grand National Assembly of Turkey and ruling the country by decree by issuing 28 new ones."

In September 12, 2010, the Amendments of 1982 Constitution were accepted by a referendum. The actual amendments to the constitution which were voted through are a "mixed bag." Some changes that were easily agreed upon concerning positive discrimination towards women, children and the handicapped, expending the protection of personal privacy and data protection, weakening the powers of the constitutional court to ban political parties. The more controversial one was article 159 that concerned the composition of the higher organs of the judicial authorities like Supreme Council of Judges and Prosecutors which makes judicial appointments. Since the Constitutional Court has sometimes acted as a crucial agent in blocking some of AKP's more controversial legislation proposals in the past such as criminalizing adultery or cancelling the head-scarf ban at public universities, the nomination process to the court was changed by

3 According to Article 91 of the 1982 Constitution, the fundamental, individual and political rights cannot be regulated by decrees. The empowering law shall define the purpose, scope, principles, and operative period of the decree having the force of law. Decrees having the force of law shall enter into force on the day of their publication in the Official Gazette. Decrees are submitted to the Grand National Assembly (GNA) of Turkey on the day of their publication in the Official Gazette. According to Constitution laws of empowering and decrees having the force of law which are based on these issues shall be discussed in the committees and in the plenary of the GNA as a priority and urgency.

4 Kaboğlu (2007) explains the relative decline in the number of decrees issued during the Erdoğan Governments by AKP's near absolute majority in the parliament and thus having the ability to obtain parliamentary approval for government bills easily and quickly. He adds that "legislature law-making process was accelerated mainly under the direction of the executive and prime minister, therefore, when the quantity of law increased, the quality decreased."

5 Cumhuriyet, November 3, 2011. It should be noted that following the failed Coup attempt on 15 July 2016, AKP Government declared "state of emergency" on 20 July, which has been renewed every three months. 
enhancing the power of the executive also. Members of judicial community, who have voiced their objections to the government, have argued that the reforms amounted to nothing more than political interference and the curtailment of judicial independence (Özbudun, 2012; Herzog, 2010).

On May 10, 2018 a new law was accepted by the ruling party majority within the parliament. The legislative power of the parliament was shifted to the government by this law, and government can issue decrees having force of law for the adaption of April 2017 Constitutional amendments.

In sum, the constitutional amendments carried out in the 1970s, the 1982 Constitution as whole, and both the 2010 and 2017 amendments to the 1982 Constitution have all affected the balance between the legislature and the executive and tilted it in favor of the executive not only by limiting the power of the legislature but also by reducing the oversight and independence of the judiciary.

\section{Electoral System}

The characteristics and structure of the opposition also affect the power of the legislature (Öniş, 2013, p.116). As noted by T. Christensen, P. Laegrid and P.G. Roness, the fragmentation of opposition in the parliament weakens the opposition parties and thus causes the executive to become stronger in relation to the legislature (2002). The numerically or ideologically fragmented parliamentary opposition would fail to form a united front and thus tend to enhance the executive hand.

Over the last 60 years Turkey's electoral system has been subjected to frequent changes. Between 1946 and 2015, Turkey held a total of eighteen parliamentary elections carried out under seven different election systems (Hale, 2008, p. 233). The majoritarian plurality system with multimember constituencies was used until 1960 in Turkey.

After 1961, six different versions of the D'Hondt Proportional Representation (PR) system were adapted in Turkey. Following the application of D'Hondt PR system (plurality system with multiple-member electoral district) in the 1961 elections, the level of party fragmentation increased and coalition governments started to appear in.

Following the 1980 coup, the military government closed down all political parties. Transition from the military rule to democracy in 1983 witnessed the emergence of numerous political parties, but the military-controlled transition process allowed only some political parties to compete in the parliamentary elections. The electoral law enacted in June 1983 has prevented political parties from acquiring any seats in the parliament unless they received a minimum of $10 \%$ of total votes (Article 33). The new law, with this high ten percent threshold, which is one of the highest in the world, was undoubtedly a key factor in limiting both intra and inter-party competition and granted the larger parties to have parliamentary representation at levels much higher than their actual votes (Hale, 2008, p. 244). The differences between the percentage of 
the popular vote and the percentage of the parliamentary seats acquired by the largest parties became more striking. These changes reduced the power of TGNA, especially related with the representation and control functions.

The 1983 electoral law, enacted with a fear of coalition governments, did not always yield majority governments; 10 of the 18 governments established since the civilian rule was restored in 1983 were either coalition or minority governments. When we examine the data for the pre and post- 1980 periods, we see a statistically significant increase in the overrepresentation in the parliament for the post-1980 period. While the average difference between the percent of votes and the percent of seats is 8.7 for the pre-1980 period, the difference jumps to $15.5 \%$ for the post- 1980 period. ${ }^{6}$ The comfortable majorities, especially enjoyed by successive ANAP Anavatan Partisi (Motherland Party) and AKP Adalet ve Kalkınma Partisi (Justice and Development Party) governments, further enhanced the power of their leaders and governments. The electoral law, which aimed at producing majority governments, inadvertently weakened the power of the parliamentary opposition and boosted the power of both the governing party and its leader. These changes in election law reduced both the representation and control functions of the TGNA.

\section{Intra-party Democracy and Leader Dominance}

The literature on party politics shows that the level of intra-party democracy in political parties affects the way the parliament functions. According to Norton, "The most pervasive constraint on legislature in the parliamentary regimes of Western Europe, however, is not the constitution but rather the party system." (1998: 192) Many scholars assume that the party or parties in the government commanded a majority in the legislature, whether in a presidential or in a parliamentary context (Blondel and Cotta, 1996, p. 5; Katz and Mayer, 2002, Offe, 1984, p.121).

Duverger has also pointed out:

In a parliamentary regime cohesion and discipline in the majority party obviously increase concentration. If voting discipline is strict, if the internal fractions are reduced to impotence or obedience, parliament's function is reduced to rubber-stamping government decisions, which are in fact identical with party decisions (1964, p. 398).

The parties in Turkey are known for highly oligarchic, authoritarian structures with a dominant leader tradition (Musil, 2015, p. 85). Party leaders play a dominant role in determining who speaks for the party in the parliament and who presents the party on legislative committees and in other functions (Turan, 1997, p. 124-125). Arguably, parliamentary system is basically a "party democracy", since the cabinet is typically formed by the majority party in the parliament and relies upon receiving the vote of confidence from the party members represented in the parliament. Therefore, parliamentary group of the governing party is in a position to influence the executive's agenda, tasks, and proposals. In return, the leader of the political party can exercise

6 ANOVA analysis of the mean differences yields an F statistics of 3.244, which is significant at the .08 level. 
power over the MPs by his/her ability to use a score of rewards and punishments for the loyal and unsupportive ones, respectively. However, it is noted that "Where the party system requires coalition governments, where coalitions are heterogeneous and expectations about their duration low, there is a strong probability that party leaders will prefer to remain in their party position, that they will keep the government at arms-length" (Blondel and Cotta, 1996, p. 250-251).

The increasing power of the executive over the legislature branch in Turkey can be attributed to the growing powers of party leaders and decline in intra-party democracy. According to Özbudun, "Deviation from the party line is rare, and if it happens the recalcitrant MP is usually expelled. This appears to be an outcome of the high degree of centralization of authority within parties, particularly the strong position of leaders" (2000, p. 86). Sayar1 attributes "The importance of leaders in shaping political outcomes" largely to "the near absolute control that they exercise over party organization" (2002, p. 3). He writes that compared to their counterparts in Western democracies, political leaders in Turkey have far greater control over their party organizations and, consequently, are better positioned to personally decide on critical domestic and foreign policy issues. Moreover, "once elected to the top party positions," Turkish political leaders "manage to stay at the heads of their parties for a very long period" (Sayar1, 2002, p. 3). In Turkey, the influence of party leadership over the parliamentary group of the governing party has become more profound over the years, which in turn reduced the influence of the parliamentary group over the executive. Thus, as noted by Kalaycıoğlu, "the government (through its majority backing in the TGNA, and the overlap of party leadership across the two branches of government) has a considerable amount of control over the legislative process in the post-1983 Parliament" (Kalaycığlu, 1990, p. 204).

A survey study conducted in 1997-1998 and included 782 party administrators from six major political parties and in 36 provinces, yielded interesting findings on the domination by party leaders in Turkey (Çarkoğlu, et al., 2000, p. 88). As shown in Table 2, a significant percent of the respondents from all parties (43-68\%) affirmed that there was "leader dominance" in their parties.

Table 2. Local party officials' views on leader dominance in political parties, 1997-1998 (N=782)

\begin{tabular}{|l|l|l|l|}
\hline Party & $\begin{array}{l}\text { Is there any leader dominance } \\
\text { in your party? Percent said Yes }\end{array}$ & $\begin{array}{l}\text { Is there any leader dominance } \\
\text { in some parties in Turkey? } \\
\text { Percent said Yes }\end{array}$ & Difference (\%) \\
\hline ANAP & 68 & 74 & 6 \\
\hline CHP & 63 & 88 & 25 \\
\hline DSP & 57 & 76 & 19 \\
\hline DYP & 55 & 77 & 22 \\
\hline MHP & 43 & 76 & 33 \\
\hline RP & 59 & 79 & 20 \\
\hline Average & 58 & 78 & 20 \\
\hline Source: Çarkoğlu, et al., (2000). Siyasi Partilerde Reform: 88, TESEV Yayınları 13, Istanbul: Acar Matbaacilık. \\
\hline
\end{tabular}


Although we do not have similar survey data from other periods to assess the change in the perception of leader domination overtime, it can be proposed that there has been an increase in the power of party leaders and decrease in intra-party democracy, partially due to the changes in laws that regulate party structures and nomination procedures (Kabasakal, 2014).

Between 1946 and 1960, parties nominated their candidates according to their bylaws. Party bylaws, devised according to national laws, allowed the party members of a given electoral district to identify the party's candidates from the district by holding primary elections within the party; the top party leadership had a limited say. The two largest parties, CHP (Cumhuriyet Halk Partisi - Republican Peoples Party) and DP (Demokrat Parti-Democratic Party), selected their candidates mainly by holding primary elections during the 1951-1960 period.

The 1961 Election Law required parties to have at least $90 \%$ of their candidates for the parliament to be selected through primary elections held among local party members (Article 15). According to the first Political Party Law, enacted in 1965, the percentage of candidates nominated by party central committees was reduced from 10 to 5 percent (Article 31). The Political Party Law was amended in 1973 and gave parties the right to decide on their candidates according to their bylaws. Nevertheless, during 1961-1980, the two largest parties, AP (Adalet Partisi, Justice Party) and CHP, generally used the primaries to select their candidates, only in a few provinces candidates were nominated by the central organs. Although the local party members' say in the nomination process varied over time and across political parties, in the 1970s, all major political parties, regardless of their ideologies held primaries before national elections.

The Law on Political Parties (enacted in 1983) maintained the primary election system, but a subsequent election law, initiated by Özal and enacted in 1986, made local primaries optional (Tuncer, 2003). Without a legal mandate, party leaders and headquarters started to avoid primaries and preferred to choose the candidates themselves. This became a norm during the last five parliamentary elections, held in 2002, 2007, 2011 and 2015. As Öniş pointed out "This is a tendency that leads to excessive leader domination, a characteristic of not only the ruling party, the AKP, but also the principal opposition parties."(2015, p. 27) Practically, all party leaders decided to choose the candidates themselves - at best, they consulted the executive bodies at party headquarters. For the 2015 June parliament elections, only CHP selected $65 \%$ of the candidates by primaries.

This trend of moving away from primaries has inevitability worked against intra-party democracy and indirectly weakened the legislative power of TGNA (Lancaster, 2014, p. 1680-4 and Kalaycıoğlu, 2018, p. 47-50). Handpicked, or largely decided by the party leaders, MPs have become less likely to challenge the party leader's decisions; they tended to support the executive acting either out of loyalty or with a concern over securing their nomination in the next elections. Such MP loyalty and meekness within the ruling party meant enhancing the power of the prime minister. 


\section{B. Global Factors}

The global factors consist of the impact of the regulations required by intergovernmental organizations and treaties signed by the country. Further, globalization enhances the trend toward technical governance and specialized policy formulation in the parliament.

\section{Increasing Global Regulations}

While all countries have been affected by the changes in world governance and subjected to regulations by intergovernmental organizations, the external regulations tend to be more profound for developing countries like Turkey. In Turkey, the influence of supra-national organizations, such as the International Monetary Fund (IMF), the Council of Europe, and the European Union (EU) has been particularly strong and increasing since 1980 (Keyman and Öniş, 2007). Knowing that, they too, would need to fulfill Turkey's obligations if they come to power, the opposition parties have not been able to challenge government policies and decisions regarding international regulations. The international regulations and Turkey's efforts to implement prescribed policies, or to adapt its laws and procedures to the internationally set standards, have defined the country's policy goals and made governments more responsive to the external demands in the post-1980 era.

These changes enhanced the power of the executive, and the link between the external regulations and executive power is best illustrated by the first Özal and Erdoğan governments, which were also majority governments that enjoyed long durations, as well as the fifth Ecevit government, which ruled for a remarkably long time (3.42 years), despite the fact that it was a coalition of three ideologically distant parties.

In 1987, the Özal government sought full membership of the EU and recognized the jurisdiction of the European Court of Human Rights in 1989. Following the acceptance of Turkey's candidature to the EU in December 1999, and soon after the EU Council of Ministers adopted the Accession Partnership in December 2000, the fifth Ecevit government issued Turkey's National Program for Adoption of the Acquis Communautaire in March 2001. Ecevit's coalition government initiated a legislative reform period that aimed at the harmonization of Turkey's laws with those of the EU, and the subsequent AKP governments continued with the reform process, at least until 2007 (Kılınç, 2014: 299-300). Then, Turkish-EU relations became weaker, due to lack of support for Turkey's membership among many EU country leaders and the increased authoritarianism in Turkey. Consequently, the impact of EU as an external regulator declined significantly.

\section{Specialization and Technical Governance}

According to Norton, “The viscosity of legislature appears to be greater where they are specialized. That specialization takes place principally through committees." (1998, p. 9) The committees are usually composed of specialized MP's (Papadopulos, 2003, p. 494). Offe defines decisionmaking procedures in parliaments as subject to the "law of reencounter". He added that "Every 
participant in parliamentary body or its committees must expect to be continually subject to the scrutiny of all the other participants with regard to all the statements he or she makes, and to be assessed on credibility, kowledge of material, sincerity, consistency, and dedication" (1996, p.94)

It is additionally noted that globalization has increased international regulations and made policy formulation more technical (Elgie and Stapleton, 2006; Raunio and Wiberg, 2008). Committee members may generally constitute informed members by virtue of their pre-legislative backgrounds or because of a degree of knowledge through ministerial office (Norton, 1998, p. 10). Examining the effectiveness of the Turkish parliament, Turan contends that the parliaments have remained slow in their responses due to the increasing specialization of issues (2000, p.16). Thus, the extent to which committees can determine their own agenda becomes particularly important. The agenda may be determined by government or some political forces. According to a former Turkish MP Emre Kocaoğlu, many issues discussed within the parliament in recent years required expertise and technical knowledge, thus, the bills were settled down to the details at parliamentary committees before they were submitted to the MPs' vote (2002). Others noted that the parliamentary committees did not function well, due to the polarization within committees and the high level of control by the ruling party leader (Kalaycığlu, 1990, p. 210-216; Kabasakal, 2016).

In sum, the process of deparliamentazation in Turkey has been unfolding since the 1970s and gained momentum after 1980. In addition to several factors that were identified as the cause of facilitator of the process in other parliamentary regimes, constitutional changes, election laws and leader dominance in political parties have been particularly important in setting the trend of decreasing power of the parliament by effecting different functions of the TGNA.

\section{Conclusion}

Although a trend of deparliamentarization has been noted, mainly in parliamentary democracies, the decline of parliaments has not been at the same level everywhere. Thus, the variation, especially among similar democratic systems, calls for a closer analysis of country cases. The power shift in Turkey during parliamentary democracy (1946-2014) has been from parliamentary supremacy to a very strong executive, and deparliamentarization has been particularly rapid and profound since the 1980 s.

The longitudinal study of changes show that deparliamentarization, or the increase in the power of the executive, was caused by multiple domestic and international factors that occurred simultaneously and reinforced each other's impact. Constitutional changes, electoral systems, laws that regulate party procedures, increasing global regulations, influence of the supra-national organizations, specialization and technical governance have all helped enhancing the power of executive and prime ministers and reduced the power of the legislature in different ways, particularly its scrutiny function. 
In addition to pointing to the importance of examining the interaction of explanatory variables, this study also points to the importance of intra-party democracy as an explanatory variable, which is not addressed in the current literature on declining parliaments. More case studies that examine intra-party democracy, leaders' behaviors, and the procedures used in selecting parliamentary candidates would allow the development of a comprehensive model that would explain the shifts in power between the legislative and the executive branches.

The findings of the study have some normative implications, as well. Since separation of powers is considered an essential element of good governance and too much increase in executive power may mean undermining elected representatives of public in the parliament, the increasing executive power, even if it happens gradually can be detrimental for democracies. Writing in 2014, Özbudun pointed out "Instruments of horizontal accountability, always weak in Turkish politics, have further weakened. Thus, the strong, loyal, and disciplined AKP majority in parliament makes accountability to the legislature ineffective." (2014, p. 163) That already weakened parliament could not resist the declaration of a state of emergency after the July 2016 coup attempt, could not prevent its constant renewal of the state of emergency and would only watch the country being ruled by decrees. While Ziya Öniş was warning that Erdoğan's "presidential term may well be accompanied by even greater concentration and monopolization of power at the center, should a constitutional reform process in the direction of a presidential system be achieved" (2015, p. 38), the April 2017 constitutional referendum, which was held under the state of emergency, legalized, though not legitimized, that concentration of power. Thus, as noted by the Venice Commission, a Turkish-style presidential system does not follow "the well-rooted tradition of parliamentarism in Turkey but would constitute a decisive break in the constitutional history of the country."7

On the prescriptive side, we may propose that all constituencies that work for democratization should pay attention to the content of the country's laws - both the constitution and other laws that regulate political parties and elections - and promote legislative reforms that would support the separation of powers, checks and balances between the government organizations, horizontal accountability, and democratic representation of parties in the parliament, and intra-party democracy.

\section{References}

Adams, J. C. (1970) The Quest for Democratic Law, The Role of Parliament in the Legislative Process, New York: Thomas Y. Crowell Company.

Aslan - Akman, C. (2012) “The 2011 Parliamentary Elections in Turkey and Challenges

Ahead for Democratic Reform Under a Dominant Party System," Mediterranean Politics, 7 (1): 77-95.

Auel, K. (2007) "Democratic Accountability and National Parliaments: Redefining the Impact of Parliamentary Scrutiny in EU Affairs," European Law Journal, 13, (4): 487-504.

Ayan - Musil, P. (2015) "Emergence of a Dominant Party System after Multipartyism: Theoretical Implications from the Case of AKP in Turkey," South European Society and Politics, (1): 71-92.

Baldwin, N. D. J. (2004) “Introduction,” The Journal of Legislative Studies, 10 (2-3): 1-3.

7 See http://www.venice.coe.int/webforms/documents/default.aspx?pdffile=cdl-ad(2017)005-e (accessed 24.08.2017) 
Baldwin, N. D. J. (ed.) (2006) “Concluding Observations: Legislative Weakness, Scrutinising Strength," in Executive Leadership and Legislative Assemblies, 295-302, London and New York: Routledge

Beer, S.H. (1973) “The Functions of Parliament," in Beer, S.H; Ulam, A.B. (eds.), .Patterns of Government, The Major Political Systems of Europe: 206-222. Third Edition, New York: Random House.

Beetham, D. and Boyle, K. (2005) Demokrasinin Temeller, 80 Soru 80 Cevap, Aslıhan Zeynep Kopuzoğlu (çev.), Ankara: Adres Yayınları.

Blondel, J. (1973) Comparative Legislatures, New Jersey: Prentice-Hall, Inc.

Blondel, J. and Cotta, M. (eds.) (1996) “Conclusion," in J. Blondel and M. Cotta (eds.), Party and Government: 49-262, London: Macmillan Press Ltd.

Bowler, S., Farrell, D. M. and Katz, R. S. (1999) "Party Cohesion, Party Discipline, and Parliaments," in S. Bowler, D. Farrell, and R. Katz, (eds.), Party Discipline and Parliamentary Government: 3-22, Columbus: Ohio State University Press

Bryce, J. (1990) “The Decline of Legislatures” (1921), reprinted in Philip Norton (ed.), Legislatures: 47-56, New York: Oxford University Press

Christensen, T., Laegreid, P. and Roness, P.G. (2002) "Increasing Parliamentary Control of the Executive? New Instruments and Emerging Effects," Journal of Legislative Studies, (1): 37-62.

Crick. B. (1990) “The Reform of Parliament,” (1964), reprinted in Philip Norton (ed.), Legislatures: 275-285, New York: Oxford University Press

Crimmins, J. and Nesbitt-Larking, P. (1996) "Canadian Prime Ministers in the House of

Commons: Patters of Intervention'. Journal of Legislative Studies, (2): 145-171.

Çarkoğlu, A., Erdem, T., Kabasakal, M. and Gençkaya, Ö. F. (2000) Siyasi Partilerde Reform, TESEV Yayınları No.13, İstanbul: Acar Matbaacilık

Çarkoğlu, A. (2011) “Turkey’s 2011 General Elections: Towards a Dominant Party System?” Insight Turkey, 13 (3): 43-62.

Dahl, R. A. (1971) Polyarchy: Participation and Opposition, New Haven: Yale University Press

Diamond, L., Linz, J. J. and Lipset, S. M. (1995) Politics in Developing Countries, Comparing Experiences with Democracy, Boulder-London: Lynne Rienner Publishers

Diamond, L. (1999) Developing Democracy, Towards Consolidation, Baltimore: The Johns Hopkins University Press.

Dunleavy, P., Jones, G.W., and O’Leary, B. (1990) "Prime Ministers and the Commons: Patterns of Behavior, 1868 to 1987," Public Administration, (1): 123-140.

Duverger, M. (1964) Political Parties, London: Methuen Elgie, R. and Stapleton, J. (2006) “Testing the Decline of Parliament Thesis: Ireland, 1923-2002," Political Studies, (54): 465-485.

Farrell, D.M. (1997) Comparing Electoral Systems, London: Prentice Hall / Harvester Wheatsheaf

Gallager, M. (2014) “Electoral Institutions and Representation," in Lawrence LeDuc, Richard

G. Niemi and Pippa Norris (eds.), Comparing Democracies 4, Elections and Voting in a Changing World:11-31, London: Sage.

Gözübüyük, Ş. (1997) Anayasa Hukuku ve Anayasa Metni, Sixth Edition, Ankara: Turhan Kitabevi

Gumuscu, S. (2013) “The Emerging Predominant Party System in Turkey," Government and Opposition, 48, (2): 223-244.

Hale, W. (2008) “The Electoral System and the 2007 Elections: Effects and Debates," Turkish Studies, 9 (2): $233-246$.

Haynes, J. (2005) Comparative Politics in a Globalizing World. Cambridge: Polity Press. 
Haynes, J. (2010) “Politics, identity and religious nationalism in Turkey, from Atatürk to the AKP”, Australian Journal of International Affairs, 64 (3): 312-327.

Herzog, M. (2010) “Analyzing Turkey’s 2010 Constitutional Referendum” (http://fpc.org.uk/fsblob/1269. pdf) (accessed Nov. 8, 2017)

Hirst, P. (1990) The Representative Democracy and Its Limits, Cambridge: Polity Press.

Hooghe, M. (2014) “Citizenship and Patricipation," in Lawrence LeDuc, Richard G. Niemi and Pippa Norris (eds.), Comparing Democracies 4, Elections and Voting in a Changing World: 58-75, London: Sage.

Kabasakal, M. (2014) "Factors influencing intra-party democracy and membership rights: The Case of Turkey," Party Politics, (5): 700-711.

Kabasakal, M. (2016) "Küreselleşmenin ve Teknik Gelişmelerin Etkisiyle Yasa Yapımında Milletvekillerine Sağlanan Desteklerin Önemi," Elektronik Mesleki Gelişim ve Araştırmalar Dergisi, 4 (2): 60-77.

Kabasakal, M. (2018) "Measuring the Decline of Parliaments: New Indicators and Turkey as an Illustrative Case," Ankara Üniversitesi SBF Dergisi, 73, (1): 269-289.

Kaboğlu, İ.Ö. (2007) Anayasa Yargısı, Avrupa Modeli ve Türkiye, Fourth Edition, Ankara: İmge Kitabevi

Kalaycıoğlu, E. (1988) “The 1983 Parliament in Turkey: Changes and Continuities," in Metin

Heper and Ahmet Evin (eds.), State Democracy and the Military Turkey in the 1980s, New York: Walter de Gruyter

Kalaycığlu, E. (1990) "Cyclical Breakdown, Redesign and Nascent Institutionalization: The Turkish Grand National Assembly," in Ulrike Liebert and Maurizio Cotta (eds.),Parliament and Democratic Consolidation in Southern Europe: 184-222, London: Pinter Publishers

Kalaycıŏlu, E. (2002) “Elections and Governance', in Sabri Sayarı and Y1lmaz Esmer (eds.), Politics, Parties and Elections in Turkey: 55-71. London: Lynne Rienner Publishers

Kalaycığlu, E. (2018) "Two elections and a political regime in crisis: Turkish politics at the crossroad," Southeast European and Black Sea Studies, 18 (1): 21-51.

Karpat, K. (1959) Turkey's Politics, The Transition to a Multi-Party System, Princeton, New Jersey: Princeton University Press

Katz, R.S. and Mair, P. (2002) "The Ascendancy of the Party in Public Office: Organizational Change in Twentieth-Century Democracies," in Richard Gunter, Jose Ramon-Montero, and Juan J. Linz (eds.), Political Parties, Old Concepts and New Challenges, NY: Oxford University Press

Keyman, E. F. and Öniş, Z. (2007) The Turkish Politics in a Changing World, Global dynamics and Domestic Transformations, Istanbul: Istanbul Bilgi University Press

Kılınç, R. (2014) “Critical Junctures, Catalysts, and Democratic Consolidation in Turkey," Political Science Quarterly, 129 (2): 293-318.

Kili, S.(1971). Turkish Constitutional Developments and Assembly Debates on the Constitutions of 1924 and 1961, Istanbul: Robert Collage Research Center

Kocaoğlu, E. (2002) .Acemi Milletvekilinin Ankara Anıları, İyi adam Yayınları Lancaster, C. (2014) “The iron law of Erdoğan: the decay from intra-party democracy to personalistic rule," Third World Quarterly, 35 (9): 1672-1690.

Laver, M. and Shepsle, K..A. (1994) "Cabinet ministers and government formation in parliamentary democracies" in Michael Laver and Kenneth A. Shepsle (eds.), Cabinet Ministers and Parliamentary Government: 3-12, Chambridge: Chambridge University Press

Laver, M. and Shepsle, K.A. (1999) "How Political Parties Emerged from the Primeval Slime: Party Cohesion, Party Discipline, and the Formation of Governments," in S. Bowler, D. Farrell, and R. Katz (eds.), Party Discipline and Parliamentary Government: 23-48. Columbus: Ohio State University Press 
LeDuc, L.,Niemi, R. G. and Norris P. (2014) “Introduction: Democracy and Autocracy," in Lawrence LeDuc, Richard G. Niemi and Pippa Norris (eds.), Comparing Democracies 4, Elections and Voting in a Changing World:1-10, London: Sage.

Liebert, U. (1990) "Parliament as a central site in democratic consolidation: a preliminary exploration," in.Ulrike Liebert and Maurizio Cotta (eds.), Parliament and Democratic Consolidation in Southern Europe: 3-30, London: Pinter Publishers

Liebert, U. and Cotta, M. (1990) Parliament and Democratic Consolidation in Southern Europe, London: Pinter Publishers

Lijphart, A. (1999) Patterns of Democracy: Government Forms and Performance in Thirty-Six Countries, New Haven: Yale University Press

Linz, J. and Stepan, A. (1996) Problems of Democratic Transition and Consolidation Southern Europe, South America, and Post-Communist Europe, Baltimore and

London: Johns Hopkins University Press

Loewenberg, G. (1971) “The Role of Parliaments in Modern Political Systems," in Gerhard

Loewenberg (ed.) Modern Parliaments: Change or Decline: 1-20, Chicago: Aldine, Atherton Inc.

Loewenberg, G,and Patterson, S. C. (1988). Comparing Legislatures, New York: University Press of America Inc.

Martin, L. W. (2004) “The Government Agenda in Parliamentary Democracies", American Journal of Political Science, 48 (3): 445-461.

National Democratic Institute for International Affairs, Legislative Research Series, Paper \# 2, Committees in Legislatures, Washington: NDI, 1996: 1-23.

Norton, P. (1998) "Introduction: The Institution of Parliaments", in P. Norton (ed.), Parliaments and Governments in Western Europe: 1-15, London: Frank Cass

Offe, C. (1984) Contradictions of the Welfare State, Edited by John Keane, Cambridge, Massachusetts: The MIT Press.

Offe, C. (1996) Modernity \& The State, East, West, Cambridge: Polity Press.

Olson, D. M. and Norton, P. (1996) "Legislatures in Democratic Transition," in David M.

Olson and Philip Norton (eds.), The New Parliaments of Central and East Europe: 1-15, London: Frank Cass

Öniş, Z. (2013). "Sharing Power: Turkey's Democratization Challenge in the Age of the AKP Hegemony," Insight Turkey, 15 (2) 103-122.

Öniş, Z. (2015) "Monopolizing the Centre: The AKP and the Uncertain Path of Turkish Democracy," The International Spectator, 50, June 2015, (2): 22-41.

Özbudun, E. (1970) Party Cohesion in Western Democracies: A Casual Analysis, Beverly Hills, CA: Sage

Özbudun, E. and Gençkaya, Ö. F. (2009) Democratization and the Politics of Constitution- Making in Turkey, Budapest: Central European University Press

Özbudun, E. (2012) “Turkey’s Search for a New Constitution,” Insight Turkey, 4 (1): 39-50.

Özbudun, E. (2014) "AKP at the Crossroads: Erdoğan's Majoritarian Drift," South European Society and Politics, (2): 155-167.

Pennock, J. R. and Smith, D.G. ( 1969) Political Science, Fifth Printing, New York: The Macmiilan Company.

Powell, G. B. Jr. (1982) Contemporary Democracies, Participation, Stability and Violence, Cambridge: Harvard University Press 
Pridham, G. (1990) "Political Parties, parliaments and democratic consolidation in southern Europe: empirical and theoretical perspectives," in Ulrike Liebert \& Maurizio Cotta(eds.), Parliament and Democratic Consolidation in Southern Europe: 225-248, London: Pinter Publishers

Puhle, H-J. (2002) "Still the age of Catch-allism? Volksparteinen and Partteienstaat in Crisis and ReEquilibration," in Richard Gunter, Jose Ramon Montero and Juan J. Linz (eds.), Political Parties, Old Concepts and New Challenges, New York: Oxford University Press

Raunio, T. R. and Wiberg, M. (2008) “The Eduskunta and the Parliamentarisation of Finnish Politics: Formally Stronger, Politically Still Weak?” West European Politics, (3): 581 - 599.

Sayar1, S. (2002) "Introduction," in Metin Heper and Sabri Sayar1 (eds.), Political Leaders and Democracy in Turkey: 1-7, Lanham: Lexington Books .

Schmitt, C. (1988) The Crisis of Parliamentary Democracy, translated by Ellen Kennedy to English, Cambridge, Massachusetts: The MIT Press.

Schmitt, C. (2006) Parlamenter Demokrasinin Krizi, A. Emre Zeybekoğlu (çev.), Ankara: Dost Kitapevi.

Schillemans, T. (2008) "Accountability in the Shadow of Hieararcy: The Horizontal Accountability of Agencies," Public Organization Review, June 2008, (8): 175-194

Schmitter, P.C. and Karl, T.L. (1991) “What Democracy Is... and Is Not," Journal of Democracy 2 (3), 75-88. Shaw, Malcolm (1990) "Committee in Legislatures" (1979), reprinted in Philip Norton (ed.), Legislatures: 237 - 270, New York: Oxford University Press

Shaw, M. (1998) “Parliamentary Committees: A Global Perspective," The Journal of Legislative Studies, 4 (1): $225-251$.

Soysal, M. (1979) Anayasanın Anlamı, Fifth Edition, İstanbul: Gerçek Yayınevi.

Strom, K. (1998) "Parliamentary Committees in European Democracies," The Journal of Legislative Studies, 4 (1): 21-59.

Sunar, İ. (2010) Demokrasi: Türkiye Serüveni, İstanbul: Doruk Yayımc1lık.

Thomas, G. P. (2004) ‘United Kingdom: The Prime Minister and Parliament', Journal of Legislative Studies, (2-3): 4-37.

Tuncer, E. (2003) Osmanlidan Günümüze Seçimler 1877-2002, Second Edition, TESAV Yayınları No.24, Ankara: Yücel Ofset Ltd. Şti.

Turan, İ. (1997) “The Turkish Legislature: From Symbolic to Substantive Representation," in Gary W. Copeland and Samuel C. Patterson (eds.), Parliament in the Modern World, Changing Institutions: 105-128, Ann Arbor: The University of Michigan Press

Turan, İ. (2000) TBMM’nin Etkinliği, TESEV Yayınları 14, İstanbul: Acar Matbaacılık.

Uluşahin, N. (2016) "Kuvvetler Ayrılığı ve Yasama - Yürütme İlişkileri,” in Mehmet Kabasakal (ed.), Türkiye’de Siyasal Yaşam: Dün, Bugün, Yarın: 39-66, İstanbul: İstanbul Bilgi Üniversitesi Yayınları 